\title{
Research
}

\section{Evaluating Successful Livelihood Adaptation to Climate Variability and Change in Southern Africa}

\author{
Henny Osbahr ${ }^{1}$, Chasca Twyman ${ }^{2}$, W. Neil Adger ${ }^{3}$, and David S. G. Thomas ${ }^{4}$
}

\begin{abstract}
This paper examines the success of small-scale farming livelihoods in adapting to climate variability and change. We represent adaptation actions as choices within a response space that includes coping but also longer-term adaptation actions, and define success as those actions which promote system resilience, promote legitimate institutional change, and hence generate and sustain collective action. We explore data on social responses from four regions across South Africa and Mozambique facing a variety of climate risks. The analysis suggests that some collective adaptation actions enhance livelihood resilience to climate change and variability but others have negative spillover effects to other scales. Any assessment of successful adaptation is, however, constrained by the scale of analysis in terms of the temporal and spatial boundaries on the system being investigated. In addition, the diversity of mechanisms by which rural communities in southern Africa adapt to risks suggests that external interventions to assist adaptation will need to be sensitive to the location-specific nature of adaptation.
\end{abstract}

Key Words: adaptation; Africa; climate change; livelihoods; resilience

\section{INTRODUCTION}

The resilience of social-ecological systems in the face of real but uncertain global climate change is critical if communities, particularly in the developing world, are to adapt to meet future challenges (Adger et al. 2003, Washington et al. 2004, Low 2005, Hulme et al. 2005, Cash et al. 2006, Walker et al. 2006, IPCC 2007, Toulmin 2009). Climate change adaptation and the building of adaptive capacity are promoted as essential for future sustainable and equitable development, particularly for places and livelihoods that are sensitive to climate variability and climate change. Adaptation to climate change has acquired importance on the international development agenda (Commission for Africa 2005, OECD 2006, Stern 2007, UNFCCC 2007). Adaptations to climate change are already occurring through government and private action. There is, however, a growing argument in the international debates on climate policy that adaptation is limited by the need for externally financed investments by governments and aid agencies in adaptation strategies and projects (Klein and Möhner 2009, Parry et al. 2009).
In these circumstances it is important to build the evidence based on adaptations that are already occurring and to identify processes of successful adaptation that potentially promote synergy with other goals of sustainable development, whether they come about by individual action or are steered by external investments and government interventions (Robinson et al. 2006). In this paper we explore characteristics that make the process of adaptation effective by focusing on social resilience, the role of social networks, institutions, and innovation, within the context of global climate change.

We build on what is known about how individuals and communities who are faced with risk manage their resources and livelihoods (Eakin 2000, Stirling 2003, Adger et al. 2009). Individuals, when faced with climatic or other risks, prioritize between elements of the production, consumption, and ecological systems in which they sit. Figure 1 represents a response space showing the links between risks, i.e., exposure, to rural livelihoods and the effects resulting from these risks, i.e., system sensitivity. The response space is the set of options open to actors trying to enact multiple livelihood

\footnotetext{
${ }^{1}$ University of Reading and Walker Institute for Climate System Research, ${ }^{2}$ University of Sheffield, ${ }^{3}$ Tyndall Centre for Climate Change Research, University of East Anglia, ${ }^{4}$ University of Oxford
} 
and development outcomes. Although our focus is response by rural communities to climate change, there are a suite of interrelated factors that trigger a need to adapt behavior and livelihoods. Only some of the potential pathways in the response space can be deemed successful in terms of well-being or other criteria. The response space includes coping strategies that are reactive, short-term actions to deal with day-to-day shocks, problems and opportunities, as well as adaptation responses that tend to be planned and often collective actions to manage change or increased intensity of events. Evidence suggests that processes of adaptation draw on natural, social, human, as well as financial capital (Lipton et al. 1996, Nel et al. 2001, Adger 2003, Ostrom et al. 2007), with actions limited by the scarcest of these assets. For example, a household may have local knowledge, labor, and natural resources but is unable to move from coping to adaptive processes because it is excluded from access to multi-institutional level networks that offer credit or information. Therefore, the process of adaptation involves issues of governance and legitimacy of actions across different scales.

Currently, understandings of the nuanced role of institutions in helping adaptations to climate disturbances remain sketchy in the literature (Gunderson 2003, Tompkins and Adger 2004, Virtanen 2005, Boyd et al. 2008). Both informal and formal institutions are critical in terms of legitimacy, governance, diffusion, and the sustainability of actions. Informal institutions tend to consist of flexible, autonomous community networks whereas formal institutions have a more structured role, often but not exclusively, with a role for the state, e.g., agricultural extension services, local civic or church groups. Both individual and collective actions within these institutions can promote components of resilience, including buffering of livelihood disturbance or climate shocks, self-organization, and adaptive capacity.

This paper explores the role of individual and collective responses within informal and formal institutions that can lead to successful livelihood adaptive processes to manage the effects of climate change and variability. We begin by discussing the normative issues of what constitutes success in the context of adaptation and our research design. We then address dimensions of social resilience based on data derived from four regions in rural southern Africa. First, we assess the ability of, and mechanisms used by, individuals and communities to cope with climate change shocks. In particular, we focus on informal institutions and social networks. Second, we assess those communities' ability to facilitate adaptive capacity, selforganization, and learning by focusing on the role of agency and formal institutions. We are interested in identifying the important functions of existing institutions as a foundation for future climate change adaptation activities. We conclude by discussing the implications of our findings for understanding equity and system resilience at different scales, and their significance for future development and policy initiatives.

\section{WHAT IS SUCCESS?}

Rural livelihoods in developing countries have been characterized paradoxically as both precarious and as immensely robust (Ellis 1993). Part of this paradox is the observation that decision making by farmers and households can be either extremely risk averse, or in other cases, highly optimized in dealing with high environmental variability and other risks (Ellis 1993, Francis 2000). Within all response spaces (Fig. 1), individuals and communities clearly have different levels of autonomy to choose livelihood pathways. The degree to which decisions are autonomous in reality is constrained by the wider economy and political environment, as well as by antecedent decisions that partly lock people into particular livelihood pathways. Actions within the response space by communities are undertaken with various implicit and explicit objectives in mind, such as diversification, risk minimization, and capital accumulation (Binns and Nel 1999, Thomas et al. 2007).

Adaptation is the adjustment of a system to moderate the effects of climate change to take advantage of new opportunities. In the context of rural livelihoods, how is success to be judged? Issues raised in the climate change literature are whether responses effective at reducing risk are legitimate actions in terms of other resource users both within and external to the community, and whether they use scarce resources efficiently (Adger et al. 2005a). Furthermore, although an adaptation may be effective for one community, it may undermine the ability of others to adapt through spatial spillovers and negative externalities. Increased diversion of surface water or extraction of groundwater for agriculture, for example, may 
Fig. 1. The conceptualized 'response space' of adaptation. Note: risks include: climate (drought, flooding, seasonality, variability, intensity of event), environmental (level of water availability, rangeland quality, degradation, soil/vegetation quality) and socioeconomic (limited knowledge, infrastructure and technology, poor health or economy, changing types of governance, culture or politics, demography, poverty).

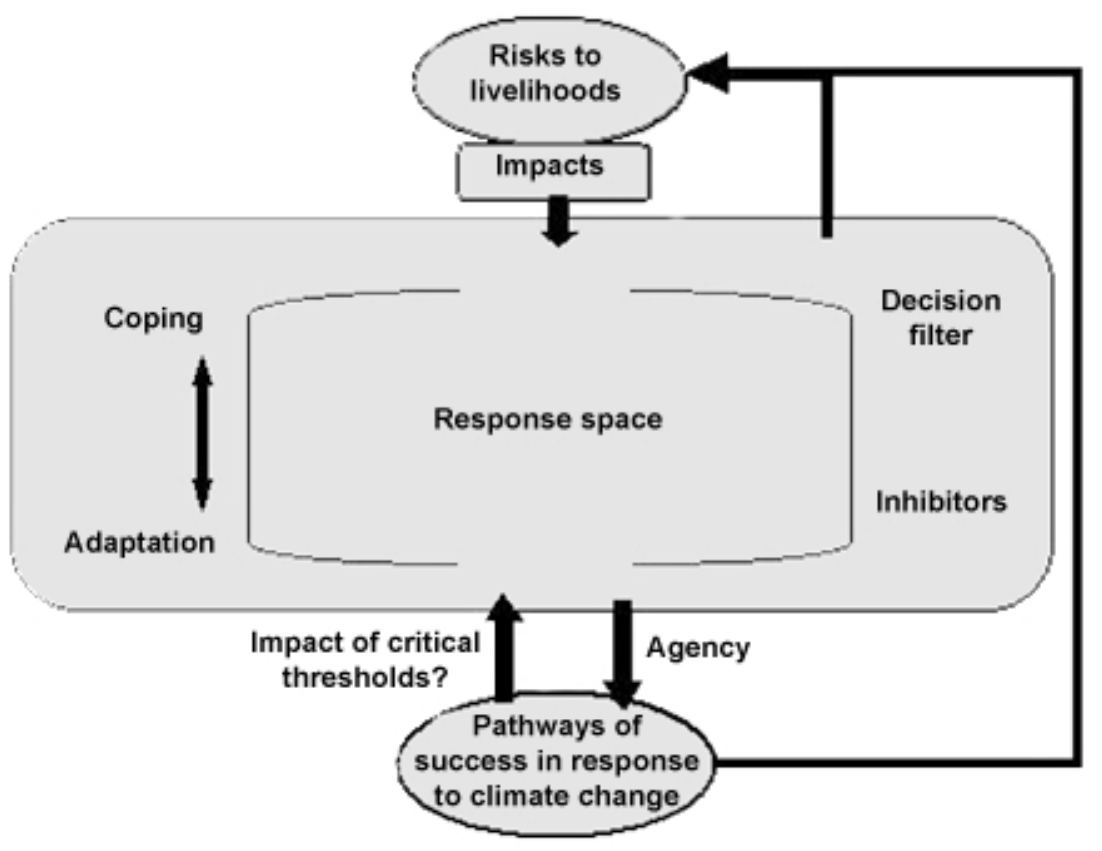

be an effective action for one set of farmers, but may jeopardize the adaptations of downstream users. Meanwhile, coping responses may reduce risk at short or immediate timescales, yet cause an increase in exposure to long-term risk.

Discussions on the success of adaptation parallel debates that seek to define the sustainability of resource use or policy intervention (Robinson et al. 2006), and thus there may be some limitations in the adaptation discourse to explain success. Insights into the resilience of social-ecological systems (Adger 2000, Gunderson and Holling 2001, Walker et al. 2004, Cumming et al. 2006, Kinzig et al. 2006, Lebel et al. 2006) suggest that many resource management practices lead to locked-in patterns of resource use that are detrimental to the ability to adapt to surprise and shock. This set of literature implicitly proposes that desirable normative goals should be the enhancement of resilience of social- ecological resource systems (Carpenter et al. 2001). This approach would allow for flexibility and perseverance of a system in a state that provides resources and services to users.

Resilience and adaptation can be considered slightly different concepts, and in this emerging paradigm resilience can be defined as "the magnitude of disturbance that can be tolerated before a socialecological system moves to a different state controlled by a different set of processes" (Carpenter et al. 2001, p. 765). A 'social-ecological system' in this case encapsulates ecosystems and their human use by communities and institutions. Resilience can be assessed through functions that determine, in the context of specific configurations and disturbances, the ability of a system to a) absorb shocks and retain its basic function, b) self-organize, and c) innovate and learn in the face of disturbances. These elements have been hypothesized as all being 
important for resilience, but the mechanisms and links between social and ecological elements of systems (Adger 2000), and the role of institutions in managing crises and disturbance (Gunderson 2003, Holling 2004, Nelson et al. 2007) have not been widely detailed.

We explore the process of success by drawing on these perspectives from resilience theory. Taking resilience theory as a starting point, we define the process of successful adaptation as that which increases system resilience but also, giving explicit treatment to governance, as that which promotes legitimate institutions to generate and sustain collective action (Lemos et al. 2007, Doria et al. 2009). The role of both individual and collective action is important in promoting self-organized adaptations. We can draw on existing understandings of the mechanisms of cooperative action within groups, diversity of management, necessary incentives, and conditions for the sustainability of such institutions (Agrawal 2002, Heyer et al. 2002). Social theory provides theoretical frameworks that conceptualize the dualities of individual actors, groups, and cultural structure, or environmental variables (Ostrom 1990, Latour 1992, Whatmore 1997, Murdoch 1998, Pelling and Hugh 2005).

In the following sections we examine social elements of what we define as successful adaptation processes in three dimensions: (1) the ability of, and mechanisms used by individuals and communities to cope with climate change shocks, i.e., to maintain function and withstand shocks, with a focus on informal institutions and social networks; (2) the ability of those communities to self-organize, via individual agency, collective networks, and formal institutions. We distinguish between those networks that are developed for instrumental reasons of exchange or economic activity and those networks that exist to promote collective action or cooperation (Fafchamps and Minten 2001, Adger 2003); and (3) adaptive capacity, which is related to the existence of mechanisms for the evolution of novelty or social learning. Through this approach, we identify the important functions of existing institutions and discuss the implications of scale and definition of system boundaries for the meaning of success.

\section{METHOD}

To assess the process of livelihood adaptation as social resilience we use empirical data, collected between 2003 and 2004 from South Africa and Mozambique (Fig. 2). Using regionalized climate analysis, four areas were identified with distinctive climate characteristics over 50 years up to 2000: regular drought, serious drought with a drying trend, increasing variability and intensity of events, and extreme flooding or drought respectively (methodology details can be found in Thomas et al. 2007). A summary of the specific climate risks from this analysis, together with other socioeconomic factors are shown in Table 1. In the future, these areas are expected to experience further extremes of their current climate (IPCC 2007, Thomas et al. 2007). Thomas et al. (2007) showed that people recognized changes in experienced climate parameters and identified them as more important to their decision making than other factors acting on their livelihoods.

Study settlements within coherent climate regions were selected in consultation with in-country partners. A cross-section of each community was selected using wealth-proxy records and advice from NGO and agricultural extension officials and local leaders, and using census material. Based on institutional divisions in the communities, 63 focus groups participated in a series of exercises covering response to disturbance, sources of income, support networks, and farming practice. These were followed by 121 household questionnaires, open and closed questions, and in-depth interviews. The main unit of analysis was the household, which was defined as those living in the same compound, and who contributed food or income to the unit. Information on assets such as labor, land use, understanding of risk, change and uncertainty, information transfer, social networks, characteristics of institutions, and household capacity was collected through these interviews with a translator. The data were illustrative of these issues. Participants represented a cross-section of the community, including both genders, different age groups, social statuses, and livelihood activities, and were selected by wealth-proxy records and advice from in-country partners. Meetings and exercises were conducted by an experienced researcher assisted by a trained translator, facilitating full group involvement and minimizing dominance by individuals. Exercises were repeated between 
Fig. 2. Location of research areas: Area 1 Mantsie, Lehurutshe District, NorthWest Province, South Africa; Area 2 Khomele, Dzanani District, Limpopo Province, South Africa; Area 3 Mcitsheni, uThukela District, KwaZulu Natal Province, South Africa; Area 4 Nwadjahane, Manjacaze District, Gaza Province, Mozambique.

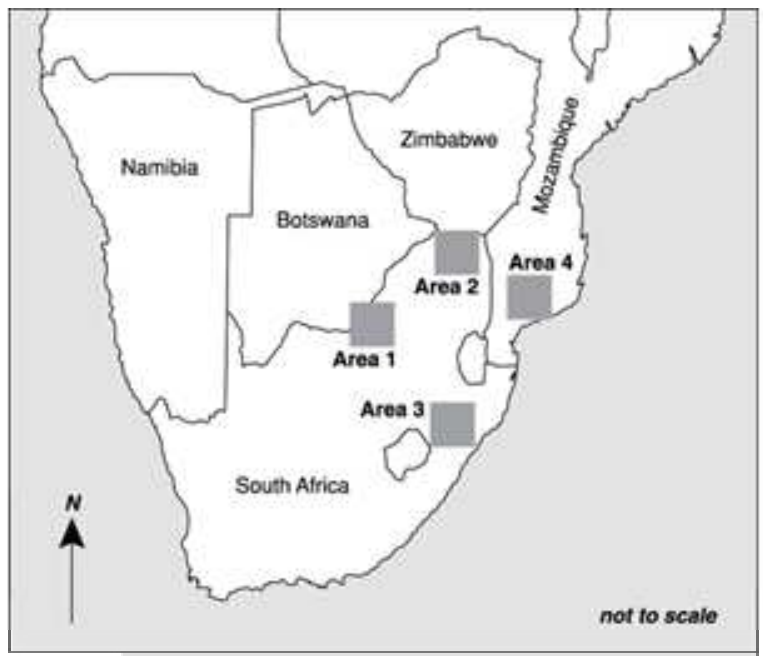

groups, some of which had overlapping membership that facilitated triangulation of findings. The time spent in the villages, participatory farm visits, plus repeat visits to villages enabled further triangulation of findings. Data analysis consisted of mixed qualitative and quantitative techniques to explore patterns in the livelihood data, coded thematic narratives, and interpretations of participatory and ranking exercises. Such a mixed methods approach is seen as fundamental to challenging received wisdoms about the 'validity' and 'truth' associated with quantitative analyses and the 'soft' and 'subjective' accounts associated with qualitative analyses (Philip 1998, Valsiner 2000). Research was discussed with, and documents collected from, district, province, and national level government, research institutes, and NGOs.

\section{THE COPING DIMENSION TO LIVELIHOODS}

Stability is understood to be the coping dimension of response to change and variability, and demonstrates the ability of people to retain basic livelihood functions while absorbing shocks, especially unpredictable climatic events. Within a household, coping is characterized by different household members responding to different shocks over a short period, and in different ways (Osbahr et al. 2008). We find similar diversified coping responses to weather-related disturbance across all the case studies, such as the selling of assets, reliance on social networks, petty trade, or temporary migration (Table 2).

Stability corresponds to the idea of persistency in social-ecological systems, however, from a resilience perspective maintaining function may not always be desirable in the long-term when trying to manage changes to the wider social-ecological system. Maintaining livelihood stability during weather-related disturbance is not about people avoiding their adaptation needs but part of the process of reframing future adaptive strategies and social institutions are important for these stability responses. In this section, we focus on understanding the informal institutions that facilitate coping responses across the different locations, essentially informal networks developed by the community without any direct role from the state. These informal networks are important for facilitating daily livelihood activities, including 
Table 1. Summary of livelihood risks across the study areas.

Study location

$\begin{array}{ll}\text { Area } 1 \text { (Mantsie village, } & \text { Area } 2 \text { (Khomele village, } \\ \text { Lehurutshe District, North } & \text { Dzanani District, Limpopo }\end{array}$

West Province, South Africa) Province, South Africa)
Area 3 (Mcitsheni village,

uThukela District, KwaZulu

Natal Province, South

Africa)
Area 4 (Nwadjahane

village, Manjacaze District, Gaza Province, Mozambique)

\section{Climate $^{\dagger}$}

Regular drought risk, unpredictable rainy seasons, $550 \mathrm{~mm}$ per year

\section{Environmental}

Water shortages, damaged dams, limited groundwater, poor quality rangeland, land degradation, bush encroachment

\section{Socioeconomic}

RSA - Botswana border divided Tswana land and social networks, 1977-94 Bophuthatswana homeland, Post-1994 restructuring of service providers, increasing HIV/AIDS, high unemployment, poverty, weak local infrastructure, dependency on welfare and remittances
Increased drought risk, unpredictable shorter rainy seasons, longer/intense dry seasons, occasional risk of intense rainfall, $525 \mathrm{~mm}$ per year
Increased risk of intense variable climatic events (snow, hail, frost, drought, floods), weak wetting trend, $845 \mathrm{~mm}$ per year
Risk of drought, unpredictable rainy seasons, risk of flooding, risk of tropical storms, $600 \mathrm{~mm}$ per year
Poor quality rangeland during droughts, some degradation, unproductive soils during drought
Poor quality rangeland, land degradation, some soil erosion
Increased woodland area around villages, loss of fertile lowland during flooding, unproductive fruit and cashew trees 1960s 'new villages' (land disputes)

1979-94 Venda homeland (important market towns, strong traditional authorities) Post-1994 restructuring of service providers, HIV/ AIDS, high unemployment, poverty, weak infrastructure, economic shocks by integrating into "new South Africa', land reform, Zimbabwean refugees
Importance of Zulu traditions Legacy of Portuguese in politics /culture, economic colonialism (migrant isolation until 1994 (legacy working, resettlement, land of townships: poverty,

overgrazing, deforestation, Post-1975 independence unemployment)

Post-1994 restructuring of service providers, decline in local industry, increased crime and HIV/AIDS socialism, communes, civil war 1983-92, Post-1994 economic shocks and institutional structuring, rising HIV/AIDS, poverty, poor services, low investment, weak infrastructure, high unemployment

$\dagger$ Information about climate for each location refers to the climatic characteristics identified from selforganized mapping using daily rainfall data from the last 50 years (Thomas et al. 2007) 
Table 2. Livelihood coping responses to climate effects across the study areas.

\begin{tabular}{lcccc}
\hline \hline & \multicolumn{3}{c}{$\begin{array}{c}\text { Respondents by area } \\
\text { Percentage of n (number of sample) }\end{array}$} \\
\cline { 2 - 5 } Response $^{\dagger}$ & $1(\mathrm{n}=30)$ & $2(\mathrm{n}=30)$ & $3(\mathrm{n}=30)$ & $4(\mathrm{n}=31)$ \\
\hline Selling of assets & $80(24)$ & $30(9)$ & $53(16)$ & $32(10)$ \\
Reliance on social networks (including money lenders) & $37(11)$ & $60(18)$ & $83(25)$ & $90(28)$ \\
Eating of wild plants/fruits & $27(8)$ & $10(3)$ & $7(2)$ & $48(15)$ \\
Eating of wild animals/birds & - & - & - & $16(5)$ \\
Turning to faith and church groups & $30(9)$ & $20(6)$ & $3(1)$ & $10(3)$ \\
Government support (e.g., welfare) & $47(14)$ & $63(19)$ & $37(11)$ & $16(5)$ \\
NGO support (e.g., food aid, cash for work) & - & - & - & $39(12)$ \\
Petty trading/hawking & $57(17)$ & $23(7)$ & $33(10)$ & $74(23)$ \\
Temporary migration (including exchange, work, support, & $83(25)$ & $43(13)$ & $43(13)$ & $35(11)$ \\
water for livestock) & & & & \\
\hline
\end{tabular}

$\dagger$ Households perform more than one type of coping response.

Note: Data collected over the 2002-4 agricultural seasons and responses recalled by interviewees for the 10 year period prior to the fieldwork

those associated with generating economic income and support (Corbett 1988, Cox 1998). It is the social structures within the village that form the basis of informal networks by binding individuals together, i.e., bonding relationships, and connecting them with others from different social and economic strata both within and beyond the village, i.e., bridging relationships (Putnam 1993).

\section{The role of informal village institutions in livelihood coping responses}

Informal networks within a village are central to the everyday system of dependence; 'bonded ties' are the reciprocal relationships between friends and family to exchange services and goods (Brouwer and Nhassengo 2006). We found informal institutions to be exclusive, defined by kinship, neighborhood, or friendship, and were loose, spontaneous, and changeable. For example, closure of a Lehurutshe local farming cooperative in area 1 (North West Province, South Africa) had forced friends in the nearby village of Mantsie to work together for the economic reason of supplying horticultural produce. To maintain these informal networks people pursue active reciprocal links with others, such as the sharing of information, emotional support, cash loans, food, or labor exchange. Maintaining these links offers individuals and households the opportunity to give and receive in times of difficulty and helps them to buffer shocks. However, only households that regularly invested in networks were able to make them part of their risk-adverse livelihood strategy. For example, in Nwadjahane village (area 4 in Gaza Province, Mozambique) informal village institutions have remained important with high rates of reciprocal labor exchange (Osbahr et al. 2008). Villagers became particularly dependent on these noncash 
exchange systems when they needed to cope during drought or flooding events. Exchange patterns reflected gender vulnerabilities, with women and female-headed households most dependent, compared with men and male-headed households, on informal networks rather than formal institutions (Osbahr et al. 2008). Although networks of exchange were relatively inclusive in Nwadjahane, with positive reinforcement of reciprocal arrangements that provided access to land and labor (Osbahr et al. 2008), in Mantsie, despite many active ties, $83 \%$ of ties were based on exclusive networks, reinforcing existing inequalities within coping mechanisms. Seventy-three percent of respondents in Mantsie believed weak trust and solidarity between households in the village and high rates of crime limited access to information, resources, or loans. In response, women had drawn on historical patterns of solidarity now using church networks, a new and popular mechanism for support for HIV/ AIDS-related illnesses, according to $53 \%$ of respondent households. As a consequence of women relying more on the church than their traditional authorities, villagers reported that attitudes had shifted from a belief in ancestral protection and the ability of traditional knowledge to manipulate nature to one of fatalism toward environmental management.

\section{The role of informal networks extending beyond the village in livelihood coping responses}

Informal institutions also generate networks between people of different classes or in other villages and urban areas; 'bridged ties' are the connecting relationships with others from different social and economic strata both within and beyond the village. These external networks must be reinforced constantly by the exchange of gifts or domestic work if they are to provide essential access to resources from outside the village during times of difficulty. Larger households were better able to initiate and maintain informal networks because they could continue to maintain household function in working the land. Large households in Khomele (area 2 in Limpopo Province, South Africa) had more receive ties, e.g., gifts or labor received by household members, and were therefore able to secure livelihood function, whereas small households were forced to resort more frequently to reactive temporary migrant work or the giving of labor for food. In both Khomele and Mcitsheni (area
3 in KwaZulu Natal Province), large households had been better able to establish a geographically wide network of ties, offering options for migrant work. Households who invested in bridged ties in Mantsie received more gifts during drought times and were able to make gifts to bridged contacts in order to hire a tractor for ploughing, allowing them to counteract the local lack of labor and cattle.

A high dependency on external networks can suggest a lack of internal village stability, a particular problem, for example, in Mcitsheni where local networks were predominately exclusive. More than half of the respondents claimed that local councilors acted as gatekeepers to government in a negative way, with the youth in particular claiming that they were unable to access formal power structures and thus felt alienated by the status quo. In Nwadjahane, the youth also claimed there was limited access to local power structures, which resulted in young men being the group least interested in farming and this directly influenced their exploitation of informal contacts outside of the village to find temporary work. Although seeking a migrant wage remains an important aspect of male identity, political and economic change in the region has forced many who had long-term jobs in mines, industry, or on commercial farms to return home to few opportunities.

The legacy of reliance on bridged ties for migrant work still had an important influence on household coping patterns and initiating opportunities. For example, although Mcitsheni experienced greater reciprocity within external networks than village networks (Fig. 3), it had the lowest ratio of give to receive ties. This indicates that the community preferred to facilitate links outside the village, especially to access temporary jobs and tractors. There had been a $27 \%$ change from long-term migrant work to temporary short-term work over the last 10 years, partly as a consequence of changing economic history in South Africa. Although vulnerability to the effects of climate change may be buffered by building a geographically wide social network, households in Mcitsheni that only invested in external ties, or in Nwadjahane in specialized dependent livelihood strategies, risked future vulnerability should they become unable to maintain the networks. Risk was not exclusive to the poor, as the wealthy were vulnerable to loss of cattle or migrant work as in Nwadjahane. In Khomele and Mcitsheni, returnees were more enthusiastic about 'modern' farming 
practices they had encountered and were most likely to seek information, disseminate ideas, or favor introducing new practice. In Mantsie, only those practicing migrant work carried out entrepreneurial activities, which became a primary source of cash. External networks and matrilineal ties to other villages were also important for gaining exposure to new information from NGO projects and to access water sources.

Households compensated for labor lost to temporary work outside the village by performing several coping actions simultaneously, each involving a different household member (Table 2). For example, the Phaswana family living in area 2 in Limpopo Province, South Africa, had farmed since the 1970s, but to pay for additional food and school fees the wife often made handicrafts to sell in nearby markets and they relied on friends for support. The family lost their crops to flooding in 2000, forcing the sale of some household goats. Extended family collected firewood to exchange locally for food for the family. Today, the household farms a cash-crop of tomatoes, asks friends for transport, and their daughters send remittances back to support the household. Thus, within the response space, feedbacks occur not only between risk, effect, and action, but also between the different actions. Significantly, not all coping responses had a positive effect on long-term livelihood resilience, nor did they have the potential to evolve into adaptive responses. For example, in Mcitsheni (area 3) a limited labor exchange system and few remittances meant that livelihoods were particularly vulnerable to the effect of a shock weather-related event. In Nwadjahane (area 4), although there were double the average number of local receive exchanges for households compared to the other villages, this did not mean the village was resilient. Eighty-seven percent of households had members away but few were sending remittances.

To return to the concept of success as the ability to absorb shocks, the findings suggest that institutional arrangements that support livelihood stability need to be carefully understood in context because they do not necessarily support adaptations or long-term resilience, and in some circumstances limit success. This is partly because certain aspects of local institutional control are highly resistant to change, especially those that perpetrate social exclusion. For example, in Mantsie (area 1), traditional leadership has remained in control despite not supporting collective action, helping secure better access to extension or health services, or reducing community vulnerability to weather-related shocks or climate trends. It is also partly because communities are only able to maintain function and buffer livelihood disturbance from weather-related events when inclusive social networks are reinforced. The implication for practitioners is to be careful not to undermine traditional safety nets, such as informal coping networks, when considering new communitybased projects. The findings discussed in this section do suggest that maintaining relationships outside the village has brought flexibility to livelihood coping strategies during times of difficulty, including access to migrant work.

\section{FACILITATING ADAPTATIONS: MECHANISMS OF SELF-ORGANIZATION AND LEARNING}

The ability to self-organize and learn both shared and new knowledge is critical to the process of innovation and livelihood resilience (Olsson et al. 2004); adaptation in the social science discourse already includes the ability to adapt through institutional organization and learning (Pelling et al. 2008). We explored both individual and collective actions to understand how the process was mediated, and the role of external institutions such as the state and international agencies in initiating collective action. These were actions to reduce vulnerability to climate change uncertainty, change, and variability (Thomas et al. 2007). Table 3 shows the four most important forms of adaptive strategies to respond to climate change effects identified by the research: agricultural changes, social capital changes, commercialization, and off-farm activities. Only off-farm activities were reliant on individual actions. In almost all other cases, collective actions facilitated changes in farming, including moves toward agricultural commercialization, and in building social capital. The role of multilevel institutional involvement, communication, heterogeneity of stakeholders, and the role of key agents were critical characteristics used to promote successful adaptation pathways through the response space.

Table 4 presents details of four specific examples of successful collective, or more formalized, adaptations from the study locations that were strongly triggered by climate change and variability (Thomas et al. 2007). The initiatives researched were identified with the advice of in-country experts from NGOs, government, and science, as well as by 
Fig. 3. Direction of reciprocity for each location. Note: Reciprocity results were generated from recorded data of all local and external exchanges for 121 households during 2003-4. These are total number of exchanges, including cash and noncash exchange, i.e.. labour, gifts and food, and represent investment in, and use of, social networks.

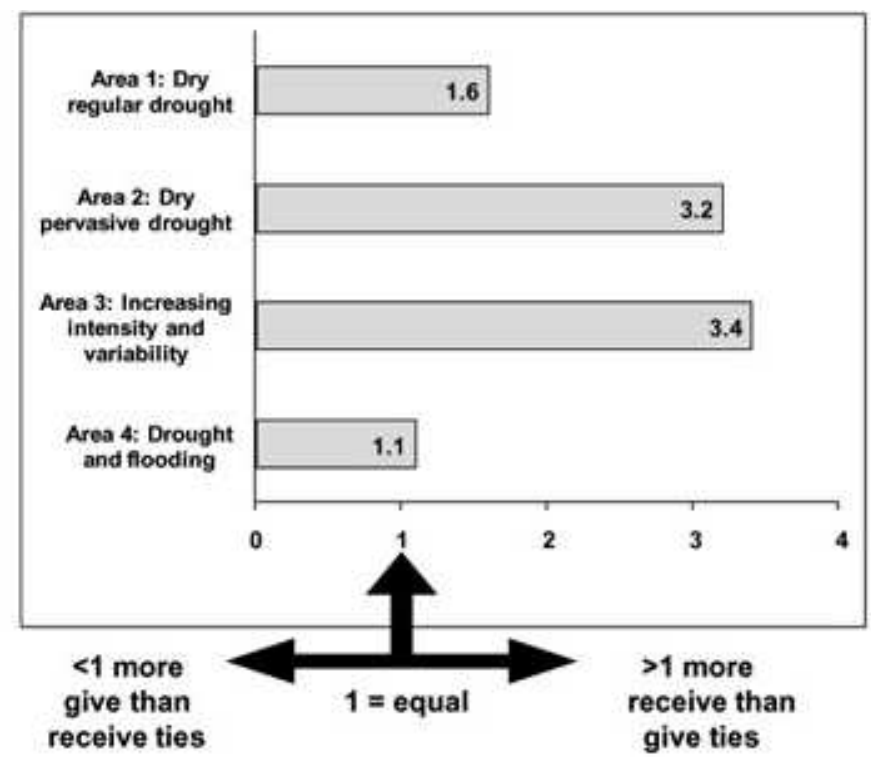

the communities themselves, to ensure that the core objective was the focus on supporting local communities to better adapt to climate change effects. Of course, in doing so they had the byproduct of additionally supporting local poverty reduction and building food insecurity; in Mozambique, concerns about climate change had been mainstreamed, i.e., they were becoming framed in the discourse of livelihoods, poverty, and food security to make them relevant to the beneficiaries of the collective action (Osbahr et al. 2008). The initiatives studied had an agricultural focus because livelihoods in each location were agriculturally dependent. The examples illustrate the nature of institutional involvement, communication, and the agency of different stakeholders. They also demonstrate that the development of specific adaptation product choices or policy prescriptions, i.e., direct adaptation measures and not integrated approaches, may not be the most useful means of promoting adaptation in agriculture to climate change or in any sector because they impose a topdown rigid pathway with limited partnership, and greater sector fragmentation. It is important that adaptation policy has a participatory, reflexive dimension that builds on existing local risk management processes (Osbahr et al. 2008).

The key mechanisms in establishing the formal farming associations (Table 4) are clear local membership structures, responsibilities being recognized by the different actors, and democratic leadership. Cooperation remained effective because confidence was increased and expertise transferred. Three of the examples also suggest that involvement of multiple actors, i.e., community members, government extension officers, and NGOs, from different institutional levels helped formal associations by providing opportunities to enhance local adaptive capacity by promoting networks of engagement, shaping human capacity by developing opportunities for improved technical/business skills, and establishing mechanisms for microfinance. Opportunities for microfinancing and business training, together with infrastructural support, will facilitate livelihood specialization and agricultural commercialization but can also finance riskspreading options that include diversification and access to land in a range of ecosystem and catchment contexts. 
Table 3. Summary of adaptation characteristics across the study areas.

\begin{tabular}{|c|c|c|c|c|}
\hline \multirow{2}{*}{$\begin{array}{l}\text { Livelihood } \\
\text { adaptations }^{\dagger} \\
\text { by theme }\end{array}$} & \multicolumn{4}{|c|}{$\begin{array}{l}\text { Respondents by area } \\
\text { Percentage of } \mathrm{n} \text { (number of sample) }\end{array}$} \\
\hline & $1(n=30)$ & $2(n=30)$ & $3(n=30)$ & $4(n=31)$ \\
\hline $\begin{array}{l}\text { Changes to agricultural } \\
\text { practice }\end{array}$ & $\begin{array}{l}27(8) \\
\text { Individual agricultural } \\
\text { experimentation, } \\
\text { fodder storage, } \\
\text { using landscape } \\
\text { diversity, traditional } \\
\text { knowledge }\end{array}$ & $\begin{array}{l}97(29) \\
\text { Structured agricultural } \\
\text { experimentation } \\
\text { (within farming } \\
\text { association) }\end{array}$ & $\begin{array}{l}40(12) \\
\text { Structured agricultural } \\
\text { experimentation, } \\
\text { conserving resources, } \\
\text { regulating/branding } \\
\text { livestock }\end{array}$ & $\begin{array}{l}68(21) \\
\text { Individual agricultural } \\
\text { experimentation, } \\
\text { planting trees, using } \\
\text { landscape diversity }\end{array}$ \\
\hline $\begin{array}{l}\text { Changes in use of } \\
\text { social capital }\end{array}$ & $\begin{array}{l}54(16) \\
\text { Investment in support } \\
\text { networks, } \\
\text { exploiting matrilineal } \\
\text { ties, building exclusive } \\
\text { networks by } \\
\text { neighborhood }\end{array}$ & $\begin{array}{l}97(29) \\
\text { Investment in support } \\
\text { networks, increasing } \\
\text { participation in } \\
\text { exclusive networks by } \\
\text { type, publicly } \\
\text { promoting social } \\
\text { cohesion }\end{array}$ & $\begin{array}{l}83(25) \\
\text { Building of male } \\
\text { maize cooperative, } \\
\text { investing in women's } \\
\text { groups, investing in } \\
\text { political networks, } \\
\text { Investment in local } \\
\text { support networks }\end{array}$ & $\begin{array}{l}84(26) \\
\text { Building of agricultural } \\
\text { cooperatives, evolved } \\
\text { traditional noncash } \\
\text { exchange mechanisms, } \\
\text { interactions between } \\
\text { traditional leaders and } \\
\text { local administration }\end{array}$ \\
\hline $\begin{array}{l}\text { Commercializing } \\
\text { livelihoods }\end{array}$ & $\begin{array}{l}23(7) \\
\text { Investment in poultry, } \\
\text { livestock }\end{array}$ & $\begin{array}{l}70(21) \\
\text { Investment in poultry, } \\
\text { livestock, collective } \\
\text { attempt to buy game } \\
\text { farm }\end{array}$ & $\begin{array}{l}53(16) \\
\text { Women's horticultural } \\
\text { collectives, some } \\
\text { livestock investment }\end{array}$ & $\begin{array}{l}16(5) \\
\text { Some investment in } \\
\text { horticulture, cashew } \\
\text { trees and livestock }\end{array}$ \\
\hline $\begin{array}{l}\text { Changing off-farm } \\
\text { roles }\end{array}$ & $\begin{array}{l}37(11) \\
\text { Regular migrant work } \\
\text { to mines and cities } \\
\text { (Zeerust, Mafiking or } \\
\text { Gaborone, Gauteng, } \\
\text { Johannesburg, } \\
\text { Rustenburg) }\end{array}$ & $\begin{array}{l}87(26) \\
\text { Regular migrant work } \\
\text { and long-term jobs } \\
\text { (Dzanani, } \\
\text { Thohanyandou, } \\
\text { Makahado, Musina, } \\
\text { Gauteng) }\end{array}$ & $\begin{array}{l}43 \text { (13) } \\
\text { Regular migrant work } \\
\text { (Ladysmith, Durban, } \\
\text { Johannesburg) }\end{array}$ & $\begin{array}{l}35(11) \\
\text { Regular migrant work } \\
\text { and long-term migrant } \\
\text { jobs (Manjacaze, Xai- } \\
\text { Xai, Maputo, South } \\
\text { Africa) }\end{array}$ \\
\hline
\end{tabular}

$\dagger$ Households perform more than one type of coping response.

Note: Data collected over the 2002-4 agricultural seasons and responses recalled by interviewees for the 10 year period prior to the fieldwork

Formal institutions in the villages included farming associations, tribal authorities, committee systems for works, water affairs, education and healthcare, civic and political groups, church membership, and women's or youth groups. The examples in Table 4 illustrate how formal institutions developed to respond to climate change and variability helped provide continuity in poverty reduction strategies and food security. In their positive sense, institutions can facilitate collective action and enable individuals to transcend the limitations of acting in isolation. In associations that had endured, members had used the bridged networks to enforce the benefits of interacting with other institutional levels, in the way described by 'adaptive governance' (Folke et al. 2005) where social networks link multiple institutional scales.

Reinforcing and expanding social networks through communication at the village-level, with strong 
Table 4. Examples of successful collective actions.

Characteristics of success

Example 1: Agricultural Cooperatives, Area 2 (Khomele, South Africa)

After 1996, agricultural extension services established agricultural projects. These endured with clear rules, structures, regular meetings, and charismatic leadership. With the introduction of Participatory Service Policy Delivery in 2004, extension officers get trained alongside local 'para-extensionists'. Benefits include access to weather forecasts, subsidized training on irrigation, advice on stock breeds, and crop. The village has been able to substitute dependence on the informal economy for the security of the association and increased commercial production. Groups have initiated access to land elsewhere for grazing livestock and growing cash crops, allowing farmers to make use of diversity in landscape and climate, including exploiting the South African land reform system. Positive reinforcement through new systems of natural resource governance consolidate networks of dependency, i.e., evolution of traditional arrangements, allow entrepreneurs to flourish, and grow new comanaged multistakeholder projects.
- Mechanisms to link formal and informal institutions with cross-scale linkages, including flow of information and credit

- Importance of rules and structures for participation and self-organization

- Strong local support and leadership

- Development of local ownership through shared knowledge production with extension officers and local decision making

- Equitable benefits, thus community happy to adapt their traditional arrangements for working together

- Inclusive networks, especially capturing key agents and entrepreneurs

Example 2: Horticultural Projects, Area 3 (Mcitsheni village, South Africa)

In 1994, agricultural extension officers gave credit to initiate horticultural projects to help smallholders adapt to a changing regional economy and unreliable intra-annual rainfall. The projects were popular, and $83 \%$ of our sample participated, mostly with women. The groups drew on existing friendship networks to establish committees, membership responsibilities, and penalties for nonparticipation. Projects have diversified the local crop base, e.g., potatoes compensate for damaged maize harvests. Vegetables are sold in nearby towns and profits reinvested, which has encouraged competition with established commercial outlets. In 2004, some projects sought business training from extension officers, which has initiated improved marketing. Motivated by success, remittances are invested in labor and irrigation pumps.
- Converted exclusive friendship informal networks into inclusive and equitable formal associations

- Clear common purpose, with importance of rules and structures for participation and self-organization

- Mechanisms for access to credit and information from the Extension Service

- Development of local ownership through local decision making, e.g., investment options for financial returns

- Diversified risk

Example 3: Maize Cooperative, Area 3 (Mcitsheni village, South Africa)

Established in 2001 by men who had returned from laboring on commercial farms. No formal mechanisms existed to stimulate innovation prior to their experimentation of shortgrowing resilient varieties and planting densities. These aimed to minimize risk to increasingly variable weather and benefited from shared resources and mechanization. Soil conservation practices, e.g., contour stone bunding, was introduced for the first time by over a third of those interviewed; fields are vulnerable during heavy rainfall before planting or after harvest. Since 2003, collective crop sales had allowed them to compete with larger landowners.
- Importance of key agents and leadership to initiate, trial, and diffuse knowledge on new technologies

- Formalized exclusive friendship networks to form a cooperative

- Reinforced enthusiasm for self-organization through financial rewards

- Economies of scale and equitable benefits 
Example 4: Farmers Associations, Area 4 (Nwadjahane, Mozambique)

Traditional leadership in Nwadjahane took advantage of changes in regional governance, increasing interaction with 'new leaders'. A number of farming associations have been initiated in the last 10 years by agricultural extension officers and NGOs, creating 'para-extensionists' to transfer information. A system of multilevel comanagement has promoted collective social resilience to climate disturbance and change (Osbahr et al. 2008). Forty-five percent of respondents now use more resilient types of cassava, beans, maize and rice than 10 years ago. Although traditional exchange systems are more numerous and pronounced than the South African locations, partly a result of limited external intervention, associations have membership rules and regular meetings that complement cultural norms and allow flexible self-organization. Even large associations have delivered opportunities for vulnerable individuals, and particularly women.
- Importance of local leadership and ability to act on opportunities

- Development of bridging relationships with actors and institutions outside the village (cross-institutional mechanisms to access information and credit)

- Formal structures reinforced cultural norms

- Development of local ownership and self-organization through coproduction of knowledge and local decision making

- Equitable benefits (mechanisms for diffusion of innovative practices) interactions between different formal and informal local institutions and between households and individuals, and with actors from other institutional scales, are clearly both crucial aspects. In cases where positive reinforcement occurred, it had encouraged further self-organization and prioritization, as well as opportunities to establish local ownership. For example, a collective irrigation scheme in area 2 in Limpopo Province established in 1996 involved visits to successful projects, loans and commercial business plans, training and experimentation with resilient crops. The scheme endured with further self-organization and commercial success for the local community. Similar structures were used to: manage village livestock auctions, to compete with commercial farmers; spin-off businesses in poultry and pigs, to improve food security; and fund a tractor and irrigation system, to allow the growing of vegetables all year. Cooperation between politicians, traditional leaders, and civic representatives was critical. In addition, the churches in Limpopo facilitated youth and women's groups, which helped to enhance a local sense of shared identity and friendship. It is important to understand the processes that shaped these examples of formal institutional initiatives, where local stakeholders work together with a government agency or NGO to undertake an aspect of adaptation to climate change and variability.

Other important factors that helped initiatives endure at local levels were the role of agency, i.e., entrepreneurs and innovators, and social learning. Transfer of knowledge was important not just between individuals but also from key individuals to the wider community. A characteristic within observed successful collective actions (see examples in Table 4) was the development of structured forums for sharing knowledge, technologies, and skills, e.g., for climate forecasts, results of new crop trials, livestock breeding, or for acquiring technical knowledge. Structured forums gave legitimacy to flexible decision making structures that promoted inclusive learning, experimentation, and local innovation, as well as further self-organization by the community. For example, in both Khomele and Nwadjahane (areas 2 and 4), 'paraextensionists' were responsible for calling meetings and sharing new information. Entrepreneurs and innovative individuals with external networks, education, or a history of migrant work, tended to take these roles because they saw them as a means to expanding their social networks and accessing information. Their involvement facilitated further group innovation in these locations, e.g., winter maize planting captured late season rains, improved organic mulches reduced costs, new tomato varieties able to withstand heat spell. Without structured forums, villagers had only slowly copied the activities of those innovators prepared to make risky investments of time and resources, such as the planting of short-maturing crop varieties in order to manage uncertainty in rainfall, or the planting of thorn hedges, contour 
ploughing, and improved mulching to control soil loss. Examples of the roles of innovators and social learning are given in Table 5.

Many youth saw young entrepreneurs as roles models, their activities reinforcing young people's belief that self-development will bring new opportunities, especially in Khomele, Mcitsheni, and Nwadjahane. Their exposure to new ideas had inspired them to copy practices from elsewhere and their spatial network secured off-farm income to invest in reciprocal exchange, extra labor, or cattle, increasing their status. Farming associations were most durable in Nwadjahane and Khomele where there were high levels of solidarity and some degree of heterogeneity of stakeholders in the case villages. By contrast, young entrepreneurs in Mantsie were frustrated by the lack of community solidarity and interaction between 'new leaders' in the municipality and traditional authorities, and according to $67 \%$ of households, this had restricted their capacity to build resistance to drought. This is a problem for this village because successful adaptation processes must capture success at the individual level and make it part of the process of collective action. Declining aspirations to farm among many youth in Mantsie casts doubt on the longer-term dominance of rainfed farming as a livelihood strategy unless such commercial adaptations develop for more households.

Proactive formal arrangements to respond to drought and seasonal variability enabled more equitable pathways of adaptation at the local level. For example, Tables 4 and 5 illustrate how regulation and accountability prevent the capture of the benefits such as information, credit, or market opportunities by only the entrepreneurs. This was because they improved communication between different stakeholders, from NGO personnel to scientists, to whom more disadvantaged households would not have otherwise had access. Smallholders were better prepared to manage a broad set of actors and respond to opportunities in the modern market. Although with differentiated success across the case studies, farmer-to-farmer learning and government training programs enabled individuals to realize their own capacity to make decisions as they move from semisubsistence livelihoods to those incorporating commercial agricultural opportunities.

\section{Are successful adaptation processes successful for all?}

Some adaptation actions such as agricultural innovation and social learning, ostensibly appear successful because they enhance livelihood resilience to climate change and variability. Some adaptation actions may, however, lead to reduction in overall system resilience if, for example, they have spillover effects to other scales (Twyman et al. 2001). In other words, responses at the general village-scale might impede responses for some at the household-scale. Identifying resilience and the process of adaptation depends on the scale of investigation. From the four regions examined, we find that decisions and actions on adaptation at the individual and household level is a competitive process, subtly differentiated by context, adaptive capacity, and perception of risk. Involvement in the mechanisms of local reciprocity, for example, remains difficult for the most vulnerable, and is compounded by informal social coping networks that often exclude the most vulnerable who are unable to participate. At the household level, members used different coping options simultaneously, but again there are inequalities when formal institutions are weak at the village level because exclusive informal social networks become more dominant. This was particularly the case in Mantsie and Nwadjahane, where small households practiced risk-adverse strategies but larger cash-rich households were able to invest in both networks of reciprocity and more specialized livelihood strategies including commercial options, thus being better able to develop social networks that offered a diversity of future options. As a consequence, they reinforced pre-existing social hierarchies, power, and entitlement inequalities.

The cooperative social networking identified in the four regions examined spawned new possibilities for access to environmental resources, suggesting that the process of successful adaptation is a learned process. Collective self-organization is important in this respect, but it is not sufficient for development practitioners to regard the creation of space for local empowerment as success in dealing with climate change effects, since it may not provide equitable outcomes at the household level. The processes were better facilitated where formal communication channels were structured among innovators or entrepreneurs, the community, and 'bridged' actors outside the village that can support the process; 
Table 5. Examples of innovation and social learning.

\author{
Characteristics Examples
}

Social learning

Example 1: Community agricultural projects (Area 2, Khomele, South Africa)

Initiated visits through matrilineal ties to other projects within the Nzhelele valley to observe pig husbandry and breeding of indigenous goats and poultry, which would be more resilient than cattle to drought. They also observed appropriate technologies for irrigation of drylands and received training from their contacts on how to repair the canals and flood-damaged dams. As a consequence, most changed to shorter growing varieties of maize and beans in the nonirrigated dry soils around the village, and changed to new tomato varieties in the irrigated fields as recommended by other farmers.

Example 2: Women's Farming Group (Area 4, Nwadjahane, Mozambique)

A group of women farmers formed through social networks with the neighboring villages of Riguane and Chalala, and copied new practices from farmers who were participating in formal agricultural projects in the area. They planted short-maturing varieties of cassava and sweet potatoes, which could be grown on the dry sandy soils during drought. The women believed that their interest in local politics and engagement with people in the projects were the reasons that the use of these new varieties had increased by $23 \%$ by the group during the year of study. The changes helped the women's subsistence households to spread the risks from variable weather.

Responsive experimentation

Example 3: Young commercial farmers (Area 2, Limpopo Province, South Africa)

Younger farmers had adapted information on agricultural practices from the scientific extension services to suit their own needs and respond to drought and variable climate. They experimented with rotators, tractors, and developed cheap water-saving techniques for irrigation. In particular, they experimented with tomato varieties to find suitable crops for the increased intense heat of the dry season, varied the spacing of plants and tried inorganic inputs. Of the farmers interviewed, $97 \%$ believed that that agricultural experimentation and innovation had helped them to try a more commercial approach to farming while remaining resilient to the changing climate in the area.

Discourse imitation

Example 4: The role of 'new leaders' (Area 2, Khomele, South Africa)

Adaptive responses are framed by social norms and local attitudes. The community was in the process of navigating between traditional identity, with 'subsistence farmers' and traditional leaders, and a new entrepreneurial attitude from outspoken 'modernizers' within formal agricultural projects, youth groups, and the civic organization. Interviews with young people highlighted that they perceived entrepreneurs in the village to be their role models and identified the importance of leaders that are able to represent new social norms and changing attitudes in rural areas in South Africa. The youth suggested that it was entrepreneurs' attitude to risk, ability to seek opportunities, and establish patron relationships beyond the village that would be necessary in their own future activities.

\title{
Conflict-resolution
}

Example 5: Formalising rules that ensure 'fairness' over local resources (Area 3, Mcitsheni, South Africa and Area 2, Khomele, South Africa) 
The autonomous formation of social groups into a men's maize cooperative and women's horticulture garden projects reduced the number of conflicts over land access and rights in Mcitsheni, and in Khomele, $43 \%$ of the total sample interviewed coordinated their tomato sales in order to limit competition for contracts to local factories in Dzanani and Musina. The autonomous formation of a village cattle auction in this location had also promoted social cohesion and reduced conflict over pricing.

participatory comanaged institutions instigate linkages to other users and promote vertical linkages to access knowledge resources and other forms of legitimacy (Adger et al. 2005b, Plummer and Armitage 2009). For example, the agricultural associations in Mcitsheni performed this function between local farmers associations, extension services, and the private horticulture sector. Only when some of the benefits of individual innovation were captured by reframed rules and responsibilities did individuals not impede the success of village level adaptation or increase differentiation in capacity through exclusive social networks. Some went further, being able to transfer benefits outside of the association to other community members, such as in Nwadjahane (Osbahr et al. 2008). It would seem that coping is competitive in nature but there are mechanisms to minimize these problems when implementing longer-term resilience and institutional reflexivity to climate change and variability.

\section{CONCLUSIONS}

This analysis has examined whether individual and collective responses within informal and formal institutions can lead to successful livelihood adaptive processes that manage the effects of climate change and variability. First, we assessed the ability of, and mechanisms used by, individuals and communities to cope with climate change shocks; persistence is not the same as ignoring adaptation needs and, from a resilience perspective, maintaining stability reframes future adaptation options. In particular, we explored the role of informal institutions and social networks. These circumstances are a reflection of livelihood context. We find that livelihood coping responses are strongly influenced by individual circumstances and that individuals within households are linked into informal social networks. These informal small groups and reciprocal networks provide flexibility in the management of livelihood disturbance over the short-term. However, they do not automatically promote adaptive capacity to climate change and variability. It would seem that bonded networks, empowerment, and high self-reliance are not enough to proactively facilitate innovation to climate change and variability. For example, we found inequality and vulnerabilities accentuated between households, with larger households better able to initiate and maintain a wider informal social network based on systems of reciprocity. The research demonstrates that local coping as a form of resilience to uncertain future climate change must not be over-emphasized since the process at both the individual and household level is competitive, subtly differentiated by climate context, household adaptive capacity, and individual perception of risk.

Second, we assessed community-level ability to facilitate increased adaptive capacity, selforganization, and learning by focusing on the role of agency and formal institutions. By focusing on the mechanisms of adaptive responses, we assessed how particular individuals and institutions mediated the process of adaptation. We found formal institutional structures offered continuity and facilitated collective actions beyond temporary cooperation. Both structural and environmental factors determine success. Where institutions captured the individual successes of key agents resulting from adaptive responses, individual success did not impede village-level adaptation or lead to inequality, and led to faster uptake of new practice. The case examples highlight how development processes can boost local resilience to climate change within specific sectors, e.g., initiatives reduced poverty, increased food security, and enhanced local capacity to manage drought, heavy rains, or variability in the agricultural sector. The process of livelihood adaptation is a learned experience, requires flexibility to negotiate the response space in a participatory way, and uses collective activities that endure over longer time scales.

Essentially, these comanagement institutions at multiple institutional scales adhere to notions of distributive decision making and reinforce inclusive 
networks but are also able to promote cross-scale vertical linkages that shape human capacity and microfinance options. These findings emphasize the importance of bridging organizational functions (Olsson et al. 2007), designed to link groups and organizations across institutional scale, while combining different sources of knowledge and promoting social learning pathways. This paper offers illustrations of the types of mechanisms that were effective, creating implications for NGOs and local government organizations and their provision of access to opportunities, nurturing of local participation, innovation, and ownership. Supporting the structural constraints that undermine local collective action should remain a central part of the adaptation agenda, e.g., poverty, lack of technical skills, finance, or institutional capacity, and national governments have the responsibility to provide planning oversight that integrates risk management, development, and adaptation at the local level.

Disentangling the pathways in the response space to provide general lessons is useful. However, it is important that not all stories of success are seen as transferable because the effects of climate change are spatially and socially differentiated. Oversimplified adaptation frameworks can lose sight of the strength in diversity and subtle differences in place-based opportunities for adaptation to changing climaterelated risks. The development agenda needs to confront the location-specific nature of adaptation to climate-related risks through building opportunities for resilience, a workable goal to promoting sustainable livelihoods in the face of uncertain change. Making resilience a specific objective for a range of policy interventions has benefits. However, we need to recognize the inevitable limits to adaptation for resource-constrained communities experiencing potentially radically altered resource availability imposed by externally driven climate shifts in the coming decades.

Responses to this article can be read online at: http://www.ecologyandsociety.org/vol15/iss2/art27/ responses/

\section{Acknowledgments:}

The authors are grateful to the Tyndall Centre for Climate Change Research at the University of East Anglia who funded this research, and for the support received during fieldwork in South Africa from
Departments of Agriculture, Livestock and Water Affairs, Nkuzi Development Association, Municipal and District Council officials, Potchefstroom University, and in Mozambique from Save the Children US, Ministry of Agriculture, SETSAN/ Fewsnet, Eduardo Mondlane University, and the National Institute of Disaster Management. Research development benefited from discussions with policy staff at Oxfam GB and the University of Cape Town, and the paper benefited from comments by two anonymous reviewers. The views expressed in this paper remain the responsibility of the authors.

\section{LITERATURE CITED}

Adger, W. N. 2000. Social and ecological resilience: are they related? Progress in Human Geography 24 (3):347-364.

Adger, W. N. 2003. Social capital, collective action and adaptation to climate change. Economic Geography 79(4):387-404.

Adger, W. N., S. Huq, K. Brown, D. Conway, and M. Hulme. 2003. Adaptation to climate change in the developing world. Progress in Development Studies 3(3): 179-195.

Adger, W. N., N. W. Arnell, and E. L. Tompkins. 2005a. Successful adaptation to climate change across scales. Global Environmental Change 15:77-86.

Adger, W. N., K. Brown, and E. L. Tompkins. $2005 \mathrm{~b}$. The political economy of cross-scale networks in resource co-management. Ecology and Society 10(2): 9. [online] URL: http://www.ecology andsociety.org/vol10/iss2/art9/.

Adger, W. N., S. Dessai, M. Goulden, M. Hulme, I. Lorenzoni, D. R. Nelson, L. Otto Naess, J. Wolf, and A. Wreford. 2009. Are there social limits to adaptation to climate change? Climatic Change $\mathbf{9 3}$ (3-4):335-354.

Agrawal, A. 2002. Common resources and institutional sustainability. Pages 41-86 in E. Ostrom, T. Dietz, N. Dolsak, P. C. Stern, S. Stonich, and E. U. Weber, editors. Drama of the commons. National Academy Press, Washington D.C., USA. 
Binns, T., and E. Nel. 1999. Beyond the development impasse: the role of local economic development and community self-reliance in rural South Africa. Journal of Modern African Studies 37 (3):389-408.

Boyd, E., H. Osbahr, P. Ericksen, E. L. Tompkins, M. C. Lemos, and F. Miller. 2008. Resilience and 'climatizing' development: examples and policy implications. Development 51(3):390-396.

Brouwer, R., and J. Nhassengo. 2006. About bridges and bonds: community responses to the 2000 floods in Mabalane District, Mozambique. Disasters 30(2):234-255.

Carpenter, S., S. Walker, J. Anderies, and N. Abel. 2001. From metaphor to measurement: resilience of what to what? Ecosystems 4:765-781.

Cash, D. W., W. N. Adger, F. Berkes, P. Garden, L. Lebel, P. Olsson, L. Pritchard, and O. Young. 2006. Scale and cross-scale dynamics: governance and information in a multilevel world. Ecology and Society 11(2): 8. [online] URL: http://www.ecology andsociety.org/voll1/iss2/art8/.

Commission for Africa. 2005. Our common interest: the report of the Africa Commission. Commission for Africa, London, UK.

Corbett, J. 1988. Famine and household coping strategies. World Development 16(9):1099-1112.

Cox, K. R. 1998. Spaces of dependence, spaces of engagement and the politics of scale, or: looking for local politics. Political Geography 17(1):1-23.

Cumming, G. S., D. H. M. Cumming, and C. L. Redman. 2006. Scale mismatches in socialecological systems: causes, consequences, and solutions. Ecology and Society 11(1): 14. [online] URL: http://www.ecologyandsociety.org/vol11/iss1/ $\underline{\operatorname{art14} / .}$.

Doria, M. D., E. Boyd, E. L. Tompkins, and W. N. Adger. 2009. Using expert elicitation to define successful adaptation to climate change. Environmental Science and Policy 12(7):810-819.

Eakin, H. 2000. Smallholder maize production and climate risk: a case study from Mexico. Climatic Change 45:19-36.
Ellis, F. 1993. Peasant economics: farm households and agrarian development. Cambridge University Press, Cambridge, UK.

Fafchamps, M., and B. Minten. 2001. Social capital and agricultural trade. American Journal of Agricultural Economics 83:680-685.

Francis, E. 2000. Making a living: changing livelihoods in rural Africa. Routledge, London, UK.

Folke, C., T. Hahn, P. Olsson, and J. Norberg. 2005. Adaptive governance of social-ecological systems. Annual Review of Environment and Resources 30:411-473.

Gunderson, L. H. 2003. Adaptive dancing: interactions between social resilience and ecological crises. Pages 33-52 in F. Berkes, J. Colding, and C. Folke, editors. Navigating socialecological systems: building resilience for complexity and change. Cambridge University Press, Cambridge, UK.

Gunderson, L., and C. S. Holling, editors. 2001. Panarchy: understanding transformations in human and natural systems. Island Press, Washington D.C., USA.

Heyer, J., F. Stewart, and R. Thorp, editors. 2002. Group behaviour and development: is the market destroying co-operation? Oxford University Press, Oxford, UK.

Holling, C. S. 2004. From complex regions to complex worlds. Ecology and Society 9(1): 11. [online] URL: http://www.ecologyandsociety.org/vol9/ iss1/art11/.

Hulme, M., R. Doherty, T. Ngara, and M. New. 2005. Global warming and African climate change: a re-assessment. Pages 29-40 in P.S. Lim, editor. Climate and Africa. Cambridge University Press, Cambridge, UK.

Intergovernmental Panel on Climate Change (IPCC). 2007. Climate change 2007: impacts, adaptation and vulnerability. M.Parry, O. Canziani, J. Palutikof, P. van der Linden, and C. Hanson, editors. Contribution of Working Group II to the Fourth Assessment Report of the Intergovernmental Panel on Climate Change. Cambridge University Press, Cambridge, UK. 
Kinzig, A. P., P. Ryan, M. Etienne, H. Allison, T. Elmqvist, and B. H. Walker. 2006. Resilience and regime shifts: assessing cascading effects. Ecology and Society 11(1): 20. [online] URL: http://www.ec ologyandsociety.org/vol11/iss1/art20/.

Klein, R. J. T., and A. Möhner. 2009. Governance limits to effective global financial support for adaptation. Pages 465-475 in W. N. Adger, I. Lorenzoni, and K. O'Brien, editors, Adapting to climate change: thresholds, values, governance. Cambridge University Press, Cambridge, UK.

Latour, B. 1992. Where are the missing masses? The sociology of a few mundane artifacts. Pages 225-264 in W. Bijker and J. Law, editors. Shaping technology / building society: studies in sociotechnical change. MIT Press, London, UK.

Lebel, L., J. M. Anderies, B. Campbell, C. Folke, S. Hatfield-Dodds, T. P. Hughes, and J. Wilson. 2006. Governance and the capacity to manage resilience in regional social-ecological systems. Ecology and Society 11(1): 19. [online] URL: http: //www.ecologyandsociety.org/vol11/iss1/art19/.

Lemos, M., E. Boyd, E. L. Tompkins, H. Osbahr, and D. Liverman. 2007. Developing adaptation and adapting development. Ecology and Society 12 (2): 26. [online] URL: http://www.ecologyandsociety. org/vol12/iss $2 / \operatorname{art} 26 /$.

Lipton, M., F. Ellis, and M. Lipton, editors. 1996. Land, labour and livelihoods in rural South Africa. Vol 2: KwaZulu-Natal and Northern Province. Indicator Press, Durban, South Africa.

Low, P. S., editor. 2005. Climate change and Africa. Cambridge University Press, Cambridge, UK.

Murdoch, J. 1998. The spaces of actor network theory. Geoforum 29(4):357-374.

Nel, E., T. Binns, and N. Motteux. 2001. Community-based development, non-governmental organisations and social capital in post-apartheid South Africa. Geografiska Annaler 83B(1):3-13.

Nelson, D. R., W. N. Adger, and K. Brown. 2007. Adaptation to environmental change: contributions of a resilience framework. Annual Review of Environment and Resources 32:395-419.
Organisation for Economic Co-operation and Development (OECD). 2006. Putting climate change adaptation in the development mainstream. Policy Briefing, OECD, Paris, France.

Olsson, P., C. Folke, and F. Berkes. 2004. Adaptive co-management for building resilience in social-ecological systems. Environmental Management 34(1):75-90.

Olsson, P., C. Folke, V. Galaz, T. Hahn, and L. Schultz. 2007. Enhancing the fit through adaptive co-management: creating and maintaining bridging functions for matching scales in the Kristianstads Vattenrike Biosphere Reserve Sweden. Ecology and Society 12(1): 28. [online] URL: http://www.e cologyandsociety.org/vol12/iss1/art28/.

Osbahr, H., C. Twyman, D. S. G. Thomas, and W. N. Adger. 2008. Effective livelihood adaptation to climate change disturbance: scale dimensions of practice in Mozambique. Geoforum 39(6):1799-2132.

Ostrom, E. 1990. Governing the commons: the evolution of institutions for collective action. Political Economy of Institutions and Decisions Series, Cambridge University Press, Cambridge, UK.

Ostrom, E., M. A. Janssen, and J. M. Andries. 2007. Going beyond panaceas. Proceedings of the National Academy of Sciences 104(39):15176-15178.

Parry, M., N. Arnell, P. Berry, D. Dodman, S. Fankhauser, C. Hope, S. Kovats, R. Nicolls, D. Sattherwaite, R. Tiffen, and T. Wheeler. 2009. Assessing the costs of adaptation to climate change: a critique of the UNFCCC estimates. International Institute for Environment and Development and Grantham Institute for Climate Change, London, UK.

Pelling, M., and C. Hugh. 2005. Social learning and adaptation to climate change. Disaster Studies Working Paper 11, Benfield Hazard Research Centre, London, UK.

Pelling, M., C. High, J. Dearing, and D. Smith. 2008. Shadow spaces for social learning: a relational understanding of adaptive capacity to climate change within organizations. Environment and Planning A 40(4):867-884. 
Philip, L. J. 1998. Combining quantitative and qualitative approaches to social research in human geography - an impossible mixture? Environment and Planning A 30(2):261-276.

Plumber, R., and D. Armitage. 2009. A resiliencebased framework for evaluating adaptive comanagement: linking ecology, economics and society in a complex world. Ecological Economics 61(1):67-74.

Putnam, R. D. 1993. Getting things done in an antimodern society: social capital and networks in Russia. Social Capital Initiative. Working Paper 6, World Bank, Washington D.C., USA.

Robinson, J., M. Bradley, P. Busby, D. Connor, A. Murrey, B. Sampson, and W. Soper. 2006. Climate change and sustainable development: realizing the opportunity. Ambio 35(1):2-8.

Stern, N. 2007. Stern review: the economics of climate change. HM Treasury, London, UK.

Stirling, A. 2003. Risk, uncertainty and precaution: some instrumental implications from the social sciences. Page 33-76 in F. Berkhout, M. Leach, and I. Scoones, editors. Negotiating environmental change: new perspectives from the social sciences. Edward Elgar, Cheltenham, UK.

Thomas, D. S. G., C. Twyman, H. Osbahr, and B. W. Hewitson. 2007. Adapting to climate change and variability in southern Africa: farmer responses to intra-seasonal precipitation trends. Climatic Change 83:301-322.

Tompkins, E. L., and W. N. Adger. 2004. Does adaptive management of natural resources enhance resilience to climate change? Ecology and Society 9 (2): 10. [online] URL: http://www.ecologyandsociety. org/vol9/iss2/art10/.

Toulmin, C. 2009. Climate Change in Africa. Zed Books, London, UK.

Twyman, C., A. Dougill, D. Sporton, and D. Thomas. 2001. Community fencing in open rangelands: self-empowerment in Eastern Namibia. Review of African Political Economy 28(87):9-26.

United Nations Framework Convention on Climate Change (UNFCCC). 2007. The Nairobi
Work Programme on Impacts, Vulnerability and Adaptation to Climate Change. Climate Change Secretariat UNFCCC, Bonn, Germany.

Valsiner, J. 2000. Data as representations: contextualizing qualitative and quantitative research strategies. Social Science Information. 39:99-113.

Virtanen, P. 2005. Community-based natural resource management in Mozambique: a critical review of the concept's applicability at local level. Sustainable Development 13:1-12.

Walker, B., C. S. Holling, S. R. Carpenter, and A. Kinzig. 2004. Resilience, adaptability and transformability in social-ecological systems. Ecology and Society 9(2): 5. [online] URL: $\underline{\text { http://w }}$ ww.ecologyandsociety.org/vo19/iss2/art5/.

Walker, B. H., L. H. Gunderson, A. P. Kinzig, C. Folke, S. R. Carpenter, and L. Schultz. 2006. A handful of heuristics and some propositions for understanding resilience in social-ecological systems. Ecology and Society 11(1): 13. [online] URL: http://www.ecologyandsociety.org/vol11/iss1/ art13/.

Washington, R., M. Harrison, and D. Conway. 2004. African Climate Report. Department for Environment, Food and Rural Affairs (DEFRA) and the Department for International Development (DFID), London, UK.

Whatmore, S. 1997. Dissecting the autonomous self. Hybrid cartographies for a relational ethics. Environment and Planning D: Society and Space 15:13-53. 